\title{
Service Quality Dimensions of E-retailing of Islamic Banks and Its Impact on Customer Satisfaction: An Empirical Investigation of Kingdom of Saudi Arabia
}

\author{
Mosab I. TABASH ${ }^{1}$, Moteb A. ALBUGAMI ${ }^{2}$, Mairaj SALIM ${ }^{3}$, Asif AKHTAR ${ }^{4}$
}

Received: April 21, 2019 Revised: April 29, 2019 Accepted: June 27, 2019

\begin{abstract}
The study aims to explore key dimensions of service quality of E-Retailing of Islamic banks in the Kingdom of Saudi Arabia. The convenience sample size consists of 373 respondents who regularly use online Islamic banking facilities in Saudi Arabia was used. For measuring the consumers' perspective, a four-factor E-SERVQUAL scale; namely efficiency, system availability, fulfillment, and privacy was used. Exploratory Factor Analysis and Confirmatory Factor Analysis are used to test the model fitness. Structural equation modelling is utilized to determine the impact of E-service quality dimensions on customers' satisfaction. The results of the study reveal that 1) reliability as a dimension of E-retailing of Islamic banks made a significant impact on customers' overall satisfaction; 2) there is a positive significant relationship between responsiveness and customers' overall satisfaction. One unit increased in responsive leads to 0.763 unit increases in the overall satisfaction of the customer; and 3) ease of use is the most important dimensions of service quality of E-retailing of Islamic banks. One unit increases in Security/ Privacy leads to 0.473 unit increases in overall satisfaction. There is a positive impact of good E-service on customers' satisfaction, but it does not override unsatisfactory performance in other areas.
\end{abstract}

Keywords: Islamic Banks, E-Retaling, Service Quality, Satisfaction, Saudi Arabia

JEL Classification Code: G20, C30, L81.

\section{Introduction}

Islamic banking industry has gained importance recently and it is growing not only in the countries following the Shariah (Islamic Laws) rules but also in the West like the UK, USA, and France. Currently, Islamic banks are playing vital

1 First Author and Corresponding Author. College of Business, Al Ain University of Science and Technology, Al Ain, UAE [Postal Address: 30 Street, Al Ain, Abu Dhabi, 64141, UAE].

Email: mosab.tabash@aau.ac.ae

2 Faculty of Economics \& Administration, King Abdulaziz University, Jeddah, Saudi Arabia.

3 Shobhit University, India.

4 Department of Business Administration, Aligarh Muslim University, Aligarh, India

(c) Copyright: Korean Distribution Science Association (KODISA)

This is an Open Access article distributed under the terms of the Creative Commons Attribution NonCommercial License (https://creativecommons.org/licenses/by-nc/4.0/) which permits unrestricted noncommercial use, distribution, and reproduction in any medium, provided the original work is properly cited. roles in enhancing economic growth and economic development (Tabash \& Dhankar 2014; Tabash, 2018). Conventional banking is already established for decades and it is very difficult in the countries not following Shariah rules to follow Islamic banking concept thus they have to face tough competition. So as to sustain a strong position in the market, Islamic banks have to improve their service quality and have to satisfy their customers by dealing with the issues faced by them. So as to attract customers and retain loyalty, Islamic banking has started offering new products according to the needs of the customers.

With the growing importance of Islamic banking globally, customer satisfaction has started becoming an important aspect and area of research. Holliday (1996), Richens (1983), and File and Prince (1992) explained that if the customers are satisfied with the services of the bank, then they will come to deal with the same bank and vice-versa. Satisfied customers are also the source of influence for others to deal with the bank. Haron, Ahmad, and Planisek 
(1994) conducted a survey on Muslim and non-Muslim customers and found out that the criteria for customer satisfaction include fast and efficient services of the bank, friendly personnel, confidentiality, and speedy transactions.

The objectives of the study are threefold: firstly, to identify the key dimensions of E-services quality on satisfaction of Islamic banks in Saudi Arabia, secondly, to investigate empirically the impact of dimensions of E-services quality on satisfaction of Islamic banks in Saudi Arabia, thirdly, to suggest /propose management strategies for the improvement of E-service quality of Islamic banks in Saudi Arabia.

\section{Literature Review}

\subsection{Services Quality in Banking}

For the survival of a banker, the service quality and customer satisfaction are necessary. Wang, Lo, and Hui (2003) argued that Islamic banks have given the importance of service quality to keep the existing customers and to attract the new customers in this competitive age. Different model has been used by the author to measure Islamic banking services quality. To measure the Islamic banking services quality Othman and Owen $(2001,2002)$ used SERVQUAL model. Fast and efficient services of the banks, responsive employees, privacy, and prompt transactions are the major determinants of the customers' satisfaction (Haron et al., 1994).

In a comparative study on conventional and Islamic banks, Ahmad, Rehman, Saif, and Safwan (2010) have suggested that for customer satisfaction the banks should focus on service quality and found that the service quality has stronger positive impact on customer satisfaction in the case of Islamic banks. Amin and Isa (2008) explore the relationship between service quality perception and customers' satisfaction. Findings of their study are that the majority of the Islamic banking customers were satisfied with the service quality provided by the banks. Satisfaction, feelings of the customers from conventional banks as well as Islamic banks are determined by the service provided by the banks (Awan, Bukhari, \& Iqbal, 2011). Parasuraman (1998) have developed a model called SERVQUAL, based on the five-dimensional models which are also used by the commercial banking institutions. SERVQUAL model was based on the products and services of the organization, its culture, technology, and environment. The study also shed light on the unclear relationship between service quality and service loyalty (Kranias, 2013).

\subsection{Dimensions of Services Quality in Banking}

Measurement of the Service quality is a multidimensional approach. Parasuraman et al. (1998) has done pioneer work on service quality measurement and identified five main dimensions i.e. tangibility, Reliability, Responsiveness, Assurance, and empathy. While in retail banking, dimensions of service quality are responsiveness, tangibility, reliability, knowledge, and accessibility (Olorunniwo \& Hsu, 2006). The tangible and physical surrounding of the services place made a significant impact on customers' response (Wakefield \& Blodgett, 1999).

Lau, Cheung, Lam, and Chu (2013) conclude that empathy, tangibility, responsiveness, reliability, and assurance were found to be significant predictors of customer satisfaction. In the specific study on customer satisfaction and service quality in Islamic banking, tangibility has been found a significant dimension of satisfaction (Rehman, 2012). A significant difference on the perception of tangibility between Islamic and conventional banking customers is found by Kumar and Charles (2010) and Manshor, Siong, Kumar, and Tat (2011). Responsiveness is another important dimension of service quality (Parasuraman, 1998; Parasuraman, Zeithaml, \& Berry, 1985). It describes its willingness to help customers and provide prompt services. In their work on e-service quality dimension, Zeithaml, Parasuraman, and Malhotra (2001) also consider responsiveness as an important dimension. In the view of online services, responsiveness is also identified as a significant services quality dimension (Tahira, Butt, de Run, \& Ramay, 2012; Ribbink, Riel, Liljander, \& Streukens, 2004; Allard, Janjaap, \& Wendy, 2003; Madu \& Madu, 2002; Barnes \& Vidgen, 2001). Some authors found that responsiveness is important for both overall service quality and customers' satisfaction. According to Kang and James (2004) in responsiveness includes timely response to e-mail requests or complaints, and confirmations of orders.

Reliability is among five dimensions of service quality after reducing the ten service quality dimensions identified by Parasuraman et al. (1998, 1985). Jun and Cai (2001) have proposed seven dimensions to improve the e-banking service quality which in turn affects customer satisfaction. Reliability among one of them. Moreover, reliability is among the 15 online service quality dimension suggested by Madu and Madu (2002) and have a place in seven service quality dimensions of e-retailing by Zeithaml et al. (2001). It is among one of the factors that have strong associations with overall service quality (Yang \& Fang, 2004). It has ranked the most important e-banking service quality dimensions (Hussien, 2013). It is also played an important role in the bank selection process in the UK by large firms (Tyler \& Stanley, 1999). Reliability, as a dimension, had made 
impacts on satisfaction and expectation of the banking customers' (Rehman, 2012; Estiri, Yazdani, Yazdani, \& Nejad, 2011; Zafar, Zaheer, \& Rehman, 2011; Arasly, Katircioglu, \& Mehtap-Smadi, 2005; Kwan \& Hee, 1994).

While Amin and Isa (2008) and Al-Tamimi and Al-Amiri (2003) found that reliability is the most important factor in service quality. In the study on generic technology-based service quality dimensions in banking, Ganguli and Roy (2011) found technology usage and reliability have a positive and significant impact on customer satisfaction and customer loyalty. Kranious (2013) revealed that the convenience-proximity dimension of quality, strongly influenced customer loyalty.

Trouble-free accessibility of any service admired by customers is considered a determining factor to determine the quality of services. Olorunniwo and Hsu (2006) have taken accessibility as service quality dimension. Availability is one of the dimensions proposed by Parasuraman, Zeithaml, and Malhotra (2005) to measuring E-services quality. This described as ease and speed of accessing and using the e-services. Cox and Dale (2001) claimed that traditional service quality dimensions are not relevant in online retailing and proposed other dimensions for it; accessibility is one of the dimensions among them. For online banking, it is also identified as a dimension to measure service quality (Joseph \& Stone, 2003; Joseph, McClure, \& Joseph, 1999).

Security is one of the ten main services quality dimension identified by Parasuraman et al. (1985). Ganguli and Roy (2011) identify technology security and information quality is one the generic service quality dimensions in the technology-based banking services. Moreover, Security is also considered one of the dimensions of e-service quality proposed by Yang, Jun, and Peterson (2004), Madu and Madu (2002), and Santos (2003). Wolfinbarger and Gilly (2003) found security among the four important factors which influence online retailing. To encourage technological based transaction, a critical barrier is security as well as quality and proper handling of information of the customers (Doll \& Torkzadeh, 1988; Kim \& Lim, 2001; Parasuraman, 2000; Van Riel, Liljander, \& Jurriens, 2001). Customers have difficulty in directly evaluating a Web site's security/privacy (Wolfinbarger \& Gilly, 2003). Jayawardhena (2004) concluded, for develop trust, banks should ensure the security and privacy of customer information.

Ease of use is the key dimensions of online service quality (Zeithaml et al., 2001). It is among the new dimension proposed in many studies specifically for those services that are based on technology (Peterson, Balasubramanian, \& Bronnenberg, 1997; Doll \& Torkzadeh, 1988). In the case of online banking services quality, ease of use is found a services quality measurement dimension
(Yang et al., 2004). It includes four items (1) easy getting access to the online web site of my bank, (2) The web site of my bank is user friendly, (3) Navigation on my bank site is easy, (4) It is easy to find my way on my bank site (Kassim \& Abdullah, 2010). "Ease of use" is one of the dimensions suggested by Jun and Cai (2001) which can affect customer satisfaction by improving the e-banking service quality. Abd El-Aziz (2009) described that there are some barriers that prevent e-banking from dominating the industry in Egypt as well as most emerging markets. Internet users in Egypt are infrequent because the E-banking services are provided but they are not easy to use. Innovative services offered by private banks are also an important determinant of customer retention and attracts new customers (Ramu \& Anbalagan, 2017).

Customer satisfaction is a psychological state of an individual. Customers are highly satisfied when service quality exceeds their expectations (Paul, Mittal, \& Srivastav, 2016). It is believed that satisfied customers keep a sustainable relationship with the company by regularly purchasing its products and services (Kashif, Suzana, Shukran, \& Rehman, 2015). It is more important for banks and financial institutions as they have few options for creating product differentiation (Al-Azzam, 2015). Lower perceived quality results in higher dissatisfaction (Omar, Saadan, \& Seman, 2015). The results of the study conducted by Zameer, Tara, Kausar, and Mohsin (2015) found a positive correlation between service quality and customer satisfaction.

\section{Research Methodology}

The main focus of this research work is to perform an empirical assessment of service quality dimensions of Eretailing of Islamic banks customers on overall satisfaction. For this purpose, a descriptive research design is followed. The research framework includes five dimensions of services quality of E-retailing for Islamic banks.

\subsection{Survey Instrument}

In order to measure key dimensions of the study, a structured questionnaire is developed. Originally thirtyseven items scale are used. Items are classified into seven dimensions of services quality and one dimension as overall customers' satisfaction. A detailed list of items with their dimension is shown in Appendix 1. Responses have been taken on five-point Likert scale where 1 stands for strongly agree, 2 stands for agree, 3 stands for neither agree nor disagree, 4 stands for disagree, 5 stands for strongly disagree. Respondents are also asked to answer questions 
regarding demographic and some other variable i.e. name of your bank and city, type of account, gender, marital status, age, occupation, education, monthly income, period (duration of usage).

\subsection{Data Collection Procedures}

In this study, data is collected by distributing the questionnaire manually. Customers are contacted in their respective Islamic banks during their visit. Convenience sampling method is used in this study. Four hundred questionnaires are filled by this method. However, 373 are found to be completed and hence considered for subsequent analysis.

\subsection{Hypotheses}

H1: There is no significant impact of reliability on the overall satisfaction of Islamic banks in Saudi Arabia.

H2: There is no significant impact of responsiveness on the overall satisfaction of Islamic banks in Saudi Arabia.

H3: There is no significant impact of accessibility on the overall satisfaction of Islamic banks in Saudi Arabia.

H4: There is no significant impact of ease to use on the overall satisfaction of Islamic banks in Saudi Arabia.

H5: There is no significant impact of security/ privacy on the overall satisfaction of Islamic banks in Saudi Arabia.

\subsection{Research Framework}

Figure 1 shows the link between the dependent variable and independent variables of the study.

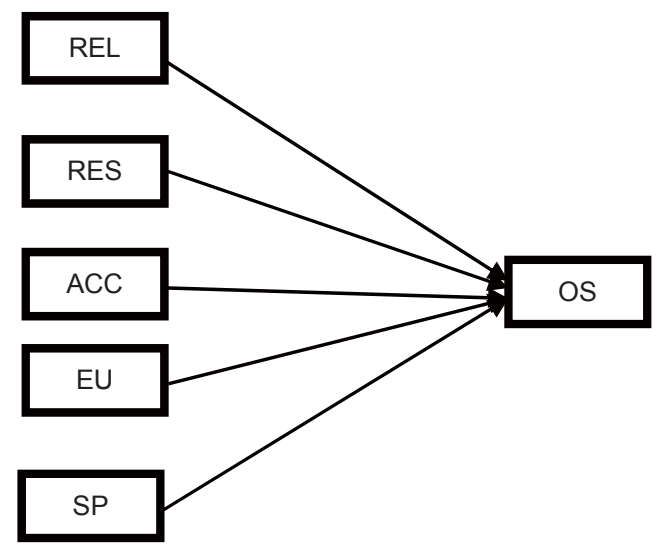

Figure 1: Framework of the study

\section{Results and Analysis}

\subsection{Demographic Profile of the Respondents}

Table 1 summarises the basic statistics on the type of bank account, gender, age, marital status, educational status, monthly income, the period of using online banking of the respondents. Data has been taken from 373 respondents of Saudi Arabia. They are the customers of different banks. $71.3 \%$ of customers are saving account holders; rest are current account holders. Majority of the respondents are male. $73.7 \%$ of the respondents are married. Most of the respondents $(48 \%)$ are in the age group of $40-49$ years old while $35.4 \%$ are in the age group 30-39 years old. It can be concluded that responses are taken from a mature group.

Occupation section of Table 1 reveals that the most of respondents are working in private jobs followed by governmental jobs. Only $13.9 \%$ are self-employed. As far as education status is concerned, the majority (38.6\%) of the respondents are graduate while only $15 \%$ of respondents are postgraduate. $44.8 \%$ of the respondents belong to income category of 5001-10000 SR (Saudi Riyal) followed by the 10001-20000 SR. These two groups constitute more than $75.5 \%$ of the respondents. Table 1 also shows that $39.4 \%$ of the respondents have 3-5 years of experience of using online banking facilities. While $30.6 \%$ of the respondents are using online banking for more than 5 years. It concludes that the majority of the respondent are familiar with online banking.

Table 1: Demographic Profile

\begin{tabular}{|c|c|c|c|}
\hline Item & Category & $\mathbf{N}$ & Percentage \\
\hline \multirow[t]{2}{*}{ Type of Account } & Saving & 266 & 71.3 \\
\hline & Current & 107 & 28.7 \\
\hline \multirow[t]{2}{*}{ Gender } & Male & 286 & 76.7 \\
\hline & Female & 87 & 23.3 \\
\hline \multirow[t]{2}{*}{ Marital Status } & Single & 98 & 26.3 \\
\hline & Married & 275 & 73.7 \\
\hline \multirow[t]{5}{*}{ Respondent Age } & 20-29 years & 27 & 7.2 \\
\hline & 30-39 years & 132 & 35.4 \\
\hline & $40-49$ years & 182 & 48.8 \\
\hline & $50-59$ & 23 & 6.2 \\
\hline & 60 and above & 9 & 2.4 \\
\hline \multirow[t]{4}{*}{ Occupation } & Government Job & 121 & 32.4 \\
\hline & Private Job & 184 & 49.3 \\
\hline & Self Employed & 52 & 13.9 \\
\hline & Others & 16 & 4.3 \\
\hline \multirow[t]{5}{*}{ Education Status } & high school & 29 & 7.8 \\
\hline & Diploma & 66 & 17.7 \\
\hline & Graduate & 144 & 38.6 \\
\hline & Post Graduate & 56 & 15 \\
\hline & Others & 78 & 20.9 \\
\hline
\end{tabular}




\begin{tabular}{|c|c|c|c|}
\hline Monthly Income & Less than 5000 SR & 52 & 13.9 \\
\hline & $5001-10000$ SR & 167 & 44.8 \\
\hline & $10001-20000$ SR & 113 & 30.3 \\
\hline & $20000-30000$ SR & 7 & 1.9 \\
\hline & Others & 34 & 9.1 \\
\hline \multirow{2}{*}{$\begin{array}{c}\text { Period of Using } \\
\text { Online Banking }\end{array}$} & Less than 1 year & 21 & 5.6 \\
\cline { 2 - 4 } & Between 1-3 years & 91 & 24.4 \\
\hline & More than 3-5 years & 147 & 39.4 \\
\hline & More than 5 years & 114 & 30.6 \\
\hline
\end{tabular}

Table 2 shows that there are five dimensions of service quality, namely Reliability, Responsiveness, Security and Privacy, Accessibility, and Ease of Use. Explanatory Factor Analysis is done to get the factor loading of the variable in the concern dimension. Component extraction method with Varimax rotation was used to do Explanatory Factor Analysis (EFA).

Table 2: Explanatory Factor Analysis

\begin{tabular}{|l|c|}
\hline \multicolumn{1}{|c|}{ Service Quality Dimension } & Factor Loading \\
\hline Reliability & \\
\hline REL1 & 0.54 \\
\hline REL2 & 0.364 \\
\hline REL5 & 0.405 \\
\hline REL3 & 0.35 \\
\hline REL6 & 0.419 \\
\hline REL8 & 0.555 \\
\hline Accessibility & \\
\hline ACC1 & 0.611 \\
\hline ACC2 & 0.353 \\
\hline ACC4 & 0.628 \\
\hline ACC5 & 0.310 \\
\hline ACC7 & 0.759 \\
\hline Ease of Use & \\
\hline EU1 & 0.754 \\
\hline EU2 & 0.707 \\
\hline EU3 & 0.394 \\
\hline EU4 & 0.767 \\
\hline EU5 & 0.661 \\
\hline Responsiveness & \\
\hline RES2 & 0.726 \\
\hline RES3 & 0.597 \\
\hline RES4 & 0.557 \\
\hline RES5 & 0.625 \\
\hline Security/ privacy & 0.328 \\
\hline SP1 & 0.575 \\
\hline SP2 & 0.697 \\
\hline SP4 & \\
\hline SP5 & \\
\hline Model Summary & \\
\hline KMO Value =0.603, Sig=0.000, & \\
\hline Total cumulative variance explained= 34.14 & \\
\hline & \\
\hline
\end{tabular}

In the Reliability (Six variables), Responsiveness (Four variables), Security and Privacy (Four variables), Accessibility (Five variables) and in Ease of Use (Five variables) are taken. KMO test has done to know the data adequacy. From that Value $(\mathrm{KMO}=0.603, \mathrm{Sig}=0.000)$, it is found that data is adequate to run the explanatory factor analysis. Total variance explained by the factor analysis is 34.14 percentage. It is somehow less than the minimum level but to make an appropriate model it must be taken. But to get the better model, only those variables are taken those have absolute factor lading more 0.3 . Total six variables have been dropped and not taken in the final model for further analysis. Another good sign of the model, no factor has multiple loading.

\subsection{Confirmatory Factor Analysis (CFA)}

EFA may suffer from some limitations like item loading more than one time which is not in the present case. Confirmatory Factor Analysis (CFA) is recommended to robust the study. CFA is used on the following factors Reliability (REL), Accessibility (ACC), Ease of use (EU), Responsiveness (RES) and Safety/privacy (SP) and the items loading on each factor were specified. The validity of the model is tested on some parameters of the model fit i.e. CMIN/DF RMR, GFI, AGFI, RMSEA, x2, nature of default model and Minimum achieved or not. Confirmatory factor analysis has done for two types of one. In the first model, the composite model is taken. In the second model, an individual model for each dimension is also checked.

Table 3 presents a summary of fit Indices for the composite model. Both GFI and AGFI values are more than the desired minimum of 0.9 and ranging from 0.991 to .915 respectively. While the value of $\mathrm{CFI}$ is 0.887 which is little less than the desired minimum 0.9, CMIN/DF 3.354 and RMSEA is at just threshold level of 0.08 . Chi-square values were significant at 3.138 and thus acceptable. Hence, the model fit indices show that goodness-of-fit measures are within acceptable levels except for CFI, which is also very nearer to reach the minimum.

Table 3: Fit Indices for Confirmatory Factor Analysis (composite model)

\begin{tabular}{|l|l|l|}
\hline Fit Indicators & Recommended Value & Observed Value \\
\hline CMIN/DF & $2.5-4.5$ & 3.354 \\
\hline GFI & $>=0.90$ & .991 \\
\hline AGFI & $>0.90$ & .915 \\
\hline CFI & $>0.90$ & .887 \\
\hline RMSEA & $<0.08$ & 0.080 \\
\hline Chi-square/df & $<5.0$ & 3.35 \\
\hline
\end{tabular}

Source: Hair et al. (2006), Arbuckle (2003), Byrne (2001) and Kline (1998) 
The overall default model is accepted, each of the constructs was evaluated separately by examining the indicator loadings for statistical significance. Further, composite reliability (CR) and total variance extracted (AVE) is also calculated for each dimension. Hair et al. (1998) suggested the minimum accepted value of CR and AVE it should be over 0.7 and 0.5 respectively. Moreover, Cronbach's alpha values are between 0.913 to 0.759 , which indicates strong internal consistency.

Table 4 and 5 present a summary of the key fit statistics. The GFI values of all dimensions are more than the minimum level 0.90 and AGFI values are also more than the bare minimum of 0.9 except for Ease of Use. AGFI value of Ease of Use is little less than 0.9. while RMSEA is also within the range except for EU. Most of the goodness of fit measure is showing appropriate value and all five defaults models are successfully run. Therefore, minimum admissible is achieved.

Table 4: Fit Indices for Confirmatory Factor Analysis (Individual model)

\begin{tabular}{|c|c|c|c|c|c|c|}
\hline Final Model & REL & ACC & EU & RES & SP & $\begin{array}{c}\text { Recommended } \\
\text { Value }\end{array}$ \\
\hline CMIN/DF & 2.321 & 0.218 & 6.849 & 0.958 & 1.421 & $2.5-4.5$ \\
\hline RMR & 0.038 & 0.007 & 0.038 & 0.013 & 0.014 & \\
\hline GFI & 0.982 & 0.999 & 0.964 & 0.997 & 0.996 & $>=0.90$ \\
\hline AGFI & 0.959 & 0.996 & 0.892 & 0.987 & 0.981 & $>0.90$ \\
\hline RMSEA & 0.060 & 0.000 & 0.125 & 0.000 & 0.034 & $<0.08$ \\
\hline$X^{2} / d f$ & 2.32 & 0.218 & 6.84 & 0.958 & 1.420 & $<5.0$ \\
\hline P & 0.13 & 0.955 & 0 & 0.384 & 0.242 & \\
\hline Default model & OK & OK & OK & OK & OK & \\
\hline Minimum achieved & Yes & yes & yes & yes & yes & \multicolumn{1}{|l|}{} \\
\hline
\end{tabular}

Table 5: Validity of Constructs

\begin{tabular}{|c|c|c|c|}
\hline & AVE(>0.5) & CR(>0.7) & A \\
\hline REL & 0.544 & 0.753 & 0.784 \\
\hline ACC & 0.493 & 0.710 & 0.759 \\
\hline EU & 0.671 & 0.812 & 0.948 \\
\hline RES & 0.585 & 0.783 & 0.865 \\
\hline SP & 0.716 & 0.884 & 0.913 \\
\hline
\end{tabular}

\subsection{Hypotheses Testing: A SEM Approach}

Table 6 presents the significant values and estimates for the hypotheses. Table 6 reveals that reliability as a dimension of E-retailing of Islamic banks made a significant impact on customers' overall satisfaction $(\beta=0.281$, $\mathrm{P}=0.04<.05)$. Hence, the hypothesis that there is no significant impact of REL on OS is rejected. If reliability of Eretailing in Islamic banking increased by 1 unit, it leads to 0.281 unit increased in customer overall satisfaction. The standardized parameter estimates and significant values $(\beta=0.763, P=0.008<.01)$ show that there is a positive significant relationship between responsiveness and customers' overall satisfaction, therefore hypothesis that there is no significant impact of RES on OS is rejected. Regression coefficient value (0.763) indicates a strong relationship between the independent and dependent variables.

One unit increased in responsive leads to 0.763 unit increases in the overall satisfaction of the customer. Among all the given determinants, responsive is the third most important factors in customer satisfaction of E-retailing of Islamic bank. Accessibility is the only service quality dimension of E-retailing in Islamic banking among all dimension which does not make a significant impact on customers' overall satisfaction. But the positive $\beta$ - value $(0.096)$ indicates that it contains a positive association with customers' satisfaction.

Statistically $(\beta=0.573, P=0.000<0.001)$ reveals that ease of use is the most important dimensions of service quality of E-retailing of Islamic banks. Hence the hypothesis there is no significant impact of Ease of Use (EU) on Overall Satisfaction (OS) is rejected. SEM results for security/ privacy $(\beta=0.437, P=0.002<0.01)$ reveals that it also makes positively and significant effect on the customers' overall satisfaction. Regression coefficient $(0.473)$ indicates that there is a high association between dependent and independent variable. One unit increases in Security/ Privacy leads to 0.473 unit increases in overall satisfaction.

Table 6: Results of Structural Equation modelling

\begin{tabular}{|c|c|c|c|c|c|}
\hline Hypothesis & $\begin{array}{l}\text { Independent } \\
\text { Variable }\end{array}$ & $\begin{array}{c}\text { Dependent } \\
\text { Variable }\end{array}$ & $\beta$ & $\mathbf{P}$ & Results \\
\hline $\mathrm{H}_{01}: \mathrm{REL} \rightarrow \mathrm{OS}$ & Reliability & Satisfaction & 0.281 & $0.04^{* *}$ & Reject \\
\hline $\mathrm{H}_{02}: \mathrm{RES} \rightarrow \mathrm{OS}$ & Responsiveness & s Satisfaction & 0.763 & $0.008^{*}$ & Reject \\
\hline $\mathrm{H}_{03}: \mathrm{ACC} \rightarrow \mathrm{OS}$ & Accessibility & Satisfaction & 0.096 & 0.564 & Accept \\
\hline $\mathrm{H}_{04}: \mathrm{EU} \rightarrow \mathrm{OS}$ & Ease of Use & Satisfaction & 0.573 & $0.000^{*}$ & Reject \\
\hline $\mathrm{H}_{05}: \mathrm{SP} \rightarrow \mathrm{OS}$ & Security/Privacy & y Satisfaction & 0.437 & $0.002^{*}$ & Reject \\
\hline
\end{tabular}

\section{Conclusions and Implications}

For the survival of the banker, a proper understanding of the service quality and customer satisfaction is a must. At a commercial level, Islamic banking is not a very old system, it should have to give more attention to the importance of service quality to keep the existing customers and to attract new customers in this competitive age. It is found that reliability is the major determinants of customers' satisfaction of Islamic banks in Saudi Arabia. These findings are in line with the similar research work (Hussien, 2013; 
Zafar et al., 2011; Estiri et al., 2011; Ganguli \& Roy, 2011; Amin \& Isa, 2008).

As far as responsiveness is concerned, it positively influences customer satisfaction in E-retailing of Islamic banking. Similar findings are reported by various researchers (Tahira et al., 2012; Rehman, 2012; Estiri et al., 2011). Accessibility as a dimension of E-retailing service quality is statistically insignificant dimension to affect customer satisfaction of Saudi Islamic banking. However, it is positively associated with customers' satisfaction. It is found from the study that for Saudi customers, ease of use is the most important service quality dimension of E-retailing of Islamic banks. It makes positive and significant impacts on customer satisfaction. It can be concluded that more ease of use of E-banking leads to higher customers' satisfaction as suggested by Yang et al. (2004). The study suggested that Privacy/security is an important service quality dimension of E-retailing considered by Saudi customers. Their satisfaction is significantly driven by the security/privacy in E-retailing of Islamic banks.

E-banking facilities must be user-friendly that is characterized by organized information, easy to understand, and clearly visible on the bank website. Much care must be given at the time of designing E-retailing platform of Islamic banking. As we know that customers are sharing highly confidential information while using E-retailing facility of the bank. It is compulsory from the banks to design secure and safe online platforms to protect their customers from any illegal share of information. Banks must adopt a proactive approach to handling customers' queries.

Employees should be trained for the prompt response. In the case of Islamic banks, reliability as a dimension is very critical. Reliability encompasses the features of the product, information about the profitability, managerial of records all through Shariah-compliant mode. This must be properly highlighted as a piece of information to the customers as most of the customers subscribed to Islamic banks as it offers Shariah-compliant products. Detailed product information and underlined mechanism of calculating risk and return should be provided on the banks' websites. A Separate team of representatives can be deployed to handle queries related to reliability of Islamic banks.

\section{References}

Abd El-Aziz, R. (2009). ATM location and usage: social and technical perspectives. Bristol, England: Doctorial dissertation, University of the West of England.

Ahmad, A., Rehman, K., Saif, I., \& Safwan, N. (2010). An empirical investigation of Islamic banking in Pakistan based on perception of service quality. African Journal of Business Management, 4(6), 1185-93.

Al-Azzam, D. A. F. M. (2015). The Impact of Service Quality Dimensions on Customer Satisfaction: A Field Study of Arab Bank in Irbid City, Jordan. European Journal of Business and Management, 7(15), 45-53.

Alam, A. (2013). Online Service Quality and Customer's Satisfaction: A Case Study of the selected Commercial Banks in Riyadh. Pensee Journal, 75(12), 188-200.

Allard, V., Janjaap, S., \& Wendy, J. (2003). E-service quality expectations: A case study, Total Quality Management \& Business Excellence, 14(4), 437-450.

Al-Tamimi, H. A. H., \& Al-Amiri, A. (2003). Analysing service quality in the UAE Islamic banks. Journal of Financial Services Marketing, 8(2), 119-132.

Amin, M., \& Isa, Z. (2008). An examination of the relationship between service quality perception and customer satisfaction: a SEM approach towards Malaysian Islamic banking. International Journal of Islamic and Middle Eastern Finance and Management, 1(3), 191-209.

Arasly, H., Katircioglu, S. T., \& Mehtap-Smadi, S. (2005). A comparison of service quality in the banking industry. International Journal of Bank Marketing, 23(7), 508-526.

Awan, M. H., Bukhari, S. K., \& Iqbal, A. (2011). Service quality and customer satisfaction in the banking sector: a comparative study of conventional and Islamic banks in Pakistan. Journal of Islamic Marketing, 2(3), 203-224.

Barnes, S. J., \& Vidgen, R. (2001). An evaluation of cyberbookshops: The WebQual method. International Journal of Electronic Commerce, 6(1), 11-30.

Butt, M. M., \& Aftab, M. (2012). Incorporating attitude towards Halal banking in an integrated service quality, satisfaction, trust and loyalty model in online Islamic banking context. International Journal of Bank Marketing, 31(1), 6-23.

Cox, J., \& Dale, B. G. (2001). Service quality and ecommerce: an exploratory analysis. Managing Service Quality, 11(2), 121-131.

Doll, W. J., \& Torkzadeh, G. (1988). The measurement of end-user computing satisfaction. MIS Quarterly, 12(2), 259-274.

Estiri, M., Hosseini, F., Yazdani, H., \& Nejad, H. J. (2011). Determinants of customer satisfaction in Islamic banking: evidence from Iran. International Journal of Islamic and Middle Eastern Finance and Management, 4(4), 295-307.

Fassnacht, M., \& Koese, I. (2006). Quality of electronic services: conceptualizing and testing a hierarchical model. Journal of Service Research, 9(1), 19-37.

File, K., \& Prince, R. (1992). Positive word-of-mouth: customer satisfaction and buyer behavior. International Journal of Bank Marketing, 10(1), 25-29. 
Ganguli, S., \& Roy, S. K. (2011). Generic technology-based service quality dimensions in banking Impact on customer satisfaction and loyalty. International Journal of Bank Marketing, 29(2), 168-189.

Haron, S., Ahmad, N., \& Planisek, S. (1994). Bank patronage factors of Muslim and non-Muslim customers. International Journal of Bank Marketing, 12(1), 32-40.

Zameer, H., Tara, A., Kausar, U., \& Mohsin, A. (2015). Impact of service quality, corporate image and customer satisfaction towards customer's perceived value in the banking sector in Pakistan. International Journal of Bank Marketing, 33(4), 442-456.

Herington, C., \& Weaven, S. (2006). E-retailing by banks: eservice quality and its importance to customer satisfaction. International Journal of Bank Marketing, 43(9/10), 12201231.

Holliday, K. (1996). Keeping close to the customer. International Journal of Bank Marketing, 28(6), 14-19.

Howell, J. M., \& Shamir, B. (2005). The role of followers in the charismatic leadership process: relationships and their consequences. Academy of Management Review, 30(1), 96-112.

Hussien, M. I. (2013). Investigating e-banking service quality in one of Egypt's banks: a stakeholder analysis. TQM Journal, 25(5), 557-576.

Jabnoun, N., \& Tamimi, H. (2003). Measuring service quality at UAE commercial banks. International Journal of Quality \& Reliability Management, 20(4), 458-472.

Jayawardhena, C. (2004). Measurement of service quality in internet banking: the development of an instrument. Journal of Marketing Management, 20(1), 185-207.

Joseph, M., \& Stone, G. (2003). An empirical evaluation of US bank customer perceptions of the impact of technology on service delivery in the banking sector. International Journal of Retail \& Distribution Management, 31(4), 190-202.

Joseph, M., McClure, C., \& Joseph, B. (1999). Service quality in the banking sector: the impact of technology on service delivery. International Journal of Bank Marketing, 17(4), 182-91

Jun, M., \& Cai, S. (2001). The key determinants of Internet Banking Service Quality: a content analysis. International Journal of Bank Marketing, 19(7), 276-291.

Kashif, M., Suzana, S., Shukran, W., \& Rehman, M. A. (2015). Customer satisfaction and loyalty in Malaysian Islamic banks: a PAKSERV investigation. International Journal of Bank Marketing, 33(1), 23-40.

Kang, G. D., \& James, J. (2004). Service Quality Dimensions: An Examination of Grönroos's Service Quality Model. Journal of Managing Service Quality, 14(4), 266-277.
Kassim, N., \& Abdullah, N. A. (2010). The effect of perceived service quality dimensions on customer satisfaction, trust, and loyalty in e-commerce settings: a cross cultural analysis. Asia Pacific Journal of Marketing and Logistics, 22(3), 351-371.

Kim, S. Y., \& Lim, Y. J. (2001). Consumers' perceived importance of and satisfaction with internet shopping. Electronic Markets, 11(3), 148-154.

Kranias, A., \& Bourlessa, M. (2013). Investigating the relationship between service quality and loyalty in Greek banking sector. Procedia Economics and Finance, 5(1), 453-458.

Kumar, M., \& Charles, V. (2010). Comparative evaluation of critical factors in delivering service quality of banks: An application of dominance analysis in. International Journal of Quality \& Reliability Management, 27(3), 352-378.

Kwan, W., \& Hee, T. J. (1994). Measuring service quality in Singapore retail banking: A gap analysis and segmentation approach. Singapore Management Review, 16(2), 1-24.

Lau, M. M., Cheung, R., Lam, A. Y., \& Chu, Y. T. (2013). Measuring service quality in the banking industry: a Hong Kong based study. Contemporary Management Research, 9(3), 263-282.

Madu, C. N., \& Madu, A.A. (2002). Dimensions of e-quality. International Journal of Quality \& Reliability Management, 19(3), 246-258.

Manshor, A. T., Siong, C. C., Kumar, M., \& Tat, K. F. (2011). Measuring service quality of conventional and Islamic banks: A comparative analysis. International Journal of Quality \& Reliability Management, 28(8), 822-840.

Masood, O., \& Bora, A. (2009). Islamic banking: a study of customer satisfaction and preferences in non-countries. International Journal of Monetary Economics and Finance, 2(3/4), 261-285.

Olorunniwo, F., \& Hsu, M. K. (2006). A typology analysis of service quality, customer satisfaction and behavioral intentions in mass services. Managing Service Quality, 16(2), 106-123.

Omar, H. F. H., Saadan, D. K. B., \& Seman, P. K. B. (2015). Determining the Influence of the Reliability of Service Quality on Customer Satisfaction: The Case of Libyan. International Journal of Learning \& Development, 5(1), 86-89.

Othman, A., \& Owen, L. (2001). Adopting and measuring customer service quality (SQ) in Islamic banks: a case study in Kuwait Finance House. International Journal of Islamic Financial Services, 3(1), 1-26.

Othman, A., \& Owen, L. (2002). The multi dimensionality of CARTER model to measure customer service quality in Islamic banking industry: a study in Kuwait finance house. 
International Journal of Islamic Financial Services, 3(4), 112.

Parasuraman, A., Zeithaml, V. A., \& Berry, L. L. (1985). A conceptual model of service quality and its implications for future research. Journal of Marketing, 49(4), 41-50.

Parasuraman, A. (1998). Service in business-to-business markets: an agenda for research. The Journal of Business \& Industrial Marketing, 13(4), 309-321.

Parasuraman, A. (2000). Technology readiness index (TRI) - a multiple-item scale to measure readiness to embrace new technologies. Journal of Service Research, 2(4), 307320.

Parasuraman, A., Zeithaml, V. A., \& Malhotra, A. (2005). ES-QUAL: A Multiple-Item Scale for Assessing Electronic Service Quality, Journal of Service Research, 7(3), 213233.

Paul, J., Mittal, A., \& Srivastav, G. (2016). Impact of service quality on customer satisfaction in private and public sector banks. International Journal of Bank Marketing, 34(5), 606-622.

Peterson, R. A., Balasubramanian, S., \& Bronnenberg, B. J. (1997). Exploring the implications of the internet for consumer marketing. Journal of the Academy of Marketing Science, 25(4), 329-346.

Ramu, G., \& Anbalagan, V. (2017), Service quality of public sector banks-a study. International Journal of Research Granthaalayah, 5(7), 639-645. https://doi.org/10.5281/zenodo.844828.

Rehman, A. (2012). Customer satisfaction and service quality in Islamic banking: A comparative study in Pakistan, United Arab Emirates and United Kingdom. Qualitative Research in Financial Markets, 4(2/3), 165175.

Ribbink, D., Riel, A., Liljander, V., \& Streukens, S. (2004). Comfort your online customer: quality, trust, and loyalty on the internet. Managing Service Quality, 14(6), 446-456.

Richens, M. L. (1983). Negative word of mouth by dissatisfied consumers: a pilot study. Journal of Marketing, 47(1), 69-78.

Rust, R., Zahorik, A. J., \& Keiningham, T. L. (1995). Return on quality (ROQ): making service quality financially accountable. Journal of Marketing, 59(1), 58-70.

Santos, J. (2003). E-service quality: A model of virtual service quality dimensions. Managing Service Quality, 13(3), 233-246.

Tabash, M., (2018). Islamic financial investments and economic growth evidence from emerging economy, United Arab Emirates. International Journal of Economics and Business Research, 15(1), 125-139.
Tabash, M., \& Dhankar, R. S. (2014). The flow of Islamic finance and economic growth: An empirical evidence of Middle East. Journal of Finance and Accounting, 2(1), 1119.

Tahira, R., Butt, M. M., de Run, E. C., \& Ramay, I. A. (2012). Measuring the e-service quality of Pakistani banks. International Journal of Economics and Business Research, 4(5), 577-589.

Tyler, K., \& Stanley, E. (1999). Marketing financial services to business: A critical review and research agenda. International Journal of Bank Marketing, 17(3), 98-115.

Van Riel, A. C. R., Liljander, V., \& Jurriens, P. (2001). Exploring consumer evaluations of e-services: A portal site. International Journal of Service Industry Management, 12(4), 359-377.

Wang, Y., Lo, H., \& Hui, Y. V. (2003). The antecedents of service quality and product quality and their influences on bank reputation: evidence from banking industry in China. Management. Service Quality Journal, 13(1), 72-83.

Wakefield, K. L., \& Blodgett, J. G. (1999). Customer response to intangible and tangible service factors. Psychology \& Marketing, 16(1), 51-68.

Wolfinbarger, M. F., \& Gilly, M. C. (2003). eTailQ: dimensionalizing, measuring and predicting etail quality. Journal of Retailing, 79(3), 183-198.

Yang, Z., Jun, M., \& Peterson, R. T. (2004). Measuring customer perceived online service quality: Scale development and managerial implications. International Journal of Operations \& Production Management, 24(11), 1149-1174.

Yang, Z., \& Fang, X. (2004). Online service quality dimensions and their relationships with satisfaction. International Journal of Service Industry Management, 15(3), 302- 326.

Yoo, B., \& Donthu, N. (2001). Developing a scale to measure the perceived quality of Internet shopping sites (SITEQUAL). Quarterly Journal of Electronic Commerce, 2(1), 31-47.

Zeithaml, V. A., Parasuraman, A., \& Malhotra, A. (2001). A conceptual framework for understanding e-service quality: Implications for future research and managerial practice (MSI Working Paper Series, Report No. 00-115).

Zafar, M., Zaheer, A., \& Rehman, K. (2011). Impact of online service quality on customer satisfaction in banking sector of Pakistan. African Journal of Business Management, 5(30), 11786-11793. 
Appendix 1: Model's dimension and variables

\begin{tabular}{|c|c|c|}
\hline Dimension & Code & Item \\
\hline \multirow{6}{*}{ Reliability } & REL1 & Precise and relevant information about product and services \\
\hline & REL2 & Provision of profit sharing investment product \\
\hline & REL5 & Profitability is by shariah compliant sources only \\
\hline & REL3 & Management of records is Accurate \\
\hline & REL6 & Taking loans are according to Islamic shariah \\
\hline & REL8 & Generation of accurate electronic bills \\
\hline \multirow{5}{*}{ Accessibility } & ACC1 & 24 hours and 7 days a week availability of customer help desk \\
\hline & ACC2 & Ease to navigate the website of the bank \\
\hline & ACC4 & Provides e-mail, sms or telephone services. \\
\hline & ACC5 & Performance of plastic card (ATM, Debit, Credit card) \\
\hline & ACC7 & Sufficient number of ATMs machines are available \\
\hline \multirow{5}{*}{ Ease of Use } & EU1 & Website provides valuable information \\
\hline & EU2 & The information on the website of the bank is well organized \\
\hline & EU3 & The information on the website is easy to understand and follow \\
\hline & EU4 & Instruction are clear and visible on the website of the bank \\
\hline & EU5 & The information on the bank web site is attractively displayed \\
\hline \multirow{4}{*}{ Responsiveness } & RES2 & 24 hours and 7 days a week availability of customer help desk \\
\hline & RES3 & Attitude of the bank employee is caring \\
\hline & RES4 & Immediate Handling of problems and queries \\
\hline & RES5 & Handling of customer's compliant on real time basis \\
\hline \multirow{4}{*}{ Security/ privacy } & SP1 & Immediate security arrangements for ATMs \\
\hline & SP2 & Personal information are kept confidential \\
\hline & SP4 & Account information are safe and secure \\
\hline & SP5 & Customer personal information exchanged will not be misused by the bank \\
\hline
\end{tabular}

